\title{
Evaluation of topographic index in relation to terrain roughness and DEM grid spacing
}

\author{
Samadrita Mukherjee ${ }^{1}$, Sandip Mukherjee ${ }^{1, *}$, R D Garg ${ }^{2}$, A Bhardwaj ${ }^{3}$ and P L N Raju ${ }^{3}$ \\ ${ }^{1}$ National Technical Research Organisation, Govt. of India, Delhi 110 001, India. \\ ${ }^{2}$ Department of Civil Engineering, Indian Institute of Technology, Roorkee 247 667, India. \\ ${ }^{3}$ Indian Institute of Remote Sensing, Indian Space Research Organisation, Dehradun 248 001, India. \\ ${ }^{*}$ Corresponding author. e-mail: sandip.iirs@gmail.com
}

Topographic index is an important attribute of digital elevation model (DEM) which indicates soil saturation. It is used for estimation of run-off, soil moisture, depth of ground water and hydrological simulation. Topographic index is derived from DEMs; hence the accuracy of DEM influences its computation. Commonly the raster based grid DEM is widely used to simulate hydrological model parameter, and accuracy varies with respect to DEM grid size and morphological characteristics of terrain. In this study topographic index is evaluated in terms of DEM grid size and terrain roughness. The study was carried out on four small watersheds, having different roughness characteristics, located over the Himalayan terrain. Topographic index surface is derived for each watershed from different grid spacing DEM (10$150 \mathrm{~m}$ ), analysed and validated. It is found that DEM grid spacing affects the topographic index. The surface representation is smooth in the coarse grid spacing and the pattern of topographic index changes with grid spacing. The spatial autocorrelation of topographic index surface reduces when calculated from larger spacing DEM. The mean of the topographic index surface increases and standard deviation decreases with the increase of grid spacing and the effect is more pronounced in the rough terrain. Accuracy of the topographic index is also evaluated with respect to grid spacing and terrain roughness by comparing the topographic index surface with respect to reference data $(10 \mathrm{~m}$ grid spacing topographic index surface). The RMSE and mean error of topographic index surface increases in larger grid spacing and the effect is more in rugged terrain.

\section{Introduction}

Terrain relief is the first order control on the various natural process of any watershed. It influences gravity and movement of water in a catchment and therefore it must be taken into account in modelling like flow path of the run-off, distribution of soil moisture and depth of the ground water level, etc. (Wolock and Price 1994). Digital elevation model (DEM) is an approximation of continuous ground surface and commonly used for the representation of terrain relief (Demoulin et al. 2007;
Yue et al. 2007; Saadat et al. 2008; Dragut and Eisank 2011). It is a quantitative representation of the Earth's surface and is typically given in one of the three formats: grid DEM, elevation in a triangulated irregular network (TIN) and digital contour. Grid DEM has been widely used to characterize the terrain relief for simulation of hydrological process. The information required for simulation can be derived from DEM in terms of primary and secondary attributes. The primary attributes are slope, aspect, profile curvature, catchment area and the secondary attributes

Keywords. Topographic index; terrain roughness; grid spacing; DEM; Cartosat-1; spatial autocorrelation. 
are upslope area, topographic index, stream power index, radiation index and temperature index (Wilson and Gallant 2000; Kennelly 2008).

Topographic index (TI) is an important parameter for natural resource management. It is used for predictive vegetation modelling (Van Niel et al. 2004), potential distribution of rainforest structural characteristics (Mackey 1994), spatial distribution of soil water (Gómez-Plaza et al. 2001), prediction for plant species number for biodiversity management (Zinko et al. 2005), spatial organization of soil moisture (Grayson et al. 1997; Western et al. 1999, 2004), mapping of soil organic matter (Pei et al. 2010), classification of landform elements from DEM (Irvin et al. 1997), mapping of landslide susceptibility (Yesilnacar and Topal 2005), identifying the relationship between crop yield and topographic variation ( $\mathrm{Si}$ and Farrell 2004), assessment of fire severity and species diversity (Wimberly and Reilly 2007), identification of ground water recharge influencing factor (Nolan et al. 2007), mapping of forest using classification of topo-climatic data (Burrough et al. 2001), etc.

Topographic index is also important in the field of hydrological modelling. It is a popular means to hydrologists to parameterize or characterize the terrain relief (Chappell et al. 2006; Kakembo et al. 2007). Topographic index has been introduced by Beven and Kirkby (1979) in their 'Topography based Watershed Model' (TOPMODEL) for characterizing the distribution of moisture status in a basin (Quinn and Beven 1993; Huang and Jiang 2002; Hjerdt et al. 2004; Tombul 2007). The effect of terrain relief on watershed hydrology is represented in TOPMODEL as the spatial distribution of the topographic index. Another hydrological model 'TOPOG' examines the pattern of surface saturation using the topographic index (O'Loughlin 1986). Topographic index is a compound terrain attribute, computed from specific catchment area of a point and the local slope (Schmidt and Persson 2003). It reflects the spatial distribution of soil saturation (Beven and Kirkby 1979) and indicates the accumulated water flow at any point in a catchment. A high value of the topographic index indicates the region has higher potential to be saturated (Raaflaub and Collins 2006). A high value of upslope drainage area and low slope results in a high topographic index, hence a high probability of occurrence of soil saturation.

Many studies used the topographic index since year 1979 and modification has been done by researchers dealing with three types of topographic indices:

(i) Topographic Index: $\operatorname{Ln}(\alpha / \tan \beta)$ also known as 'Wetness Index' or 'TOPMODEL topographic index', where $\alpha$ (specific catchment area) represents upslope area per unit contour length which means the area above a certain contour that contributes flow across the contour. It indicates the amount of water that can flow through location. For grid data, contour length is equivalent to grid spacing, and $\tan \beta$ is local down slope (Raaflaub and Collins 2006).

(ii) Soil topographic index: $\log (\alpha / T \tan \beta)$ where $\alpha$ is drainage area per unit contour length and $T$ is lateral transmissivity of soil (Merot et al. 2003).

(iii) Climato-topographic index: $\log (V r / \tan \beta)$ where $V r$ is volume of annual precipitation (Merot et al. 2003).

Topographic index is derived from a DEM. Like other spatial datasets, DEMs are subjected to different types of errors such as gross errors during data collection, deficient orientation of stereo images (systematic error) when photogrammetrically determining elevation values, transformation method of control points, mathematical model used for construction of surface and random error. The other issues related to DEM accuracy are grid spacing, interpolation techniques used and morphological characteristics of terrain (Tempfli 2000; Yue et al. 2007). Hence, the errors associated with the DEMs affect the accuracy of the topographic index (Peifa et al. 2006). Researchers have analysed the various properties of topographic index. Vaze et al. (2010) studied the effect of DEM grid spacing on topographic indices and found that the slight change in maximum and minimum elevation and substantial change in elevation difference in the coarser spacing DEM. The mean of slope decreases and variation in calculation of hillshade and stream network are found in coarse grid spacing DEM. Mean of topographic index increases progressively with DEM grid spacing which negatively affects the efficiency of model prediction (Brasington and Richards 1998). Zhang and Montgomery (1994) found that as topographic index value increases progressively in higher grid spacing, the percentage of predicted saturated area calculation also increased. Significant difference was found in the spatial pattern of topographic index computed from 5 to $50 \mathrm{~m}$ grid spacing DEMs (Quinn et al. 1991). Wolock and Price (1994) generated the elevation model from 1:24,000 and 1:250,000 scale toposheets and compared the effect of both DEMs map scale and data resolution on the statistics of topographic index and found that mean of topographic index increases with increase of grid size. The effect of DEM error on topographic index was investigated by using Monte Carlo Simulation (Raaflaub and Collins 2006), suggested that error of topographic index is more sensitive to 
the number of neighbours used in the slope algorithm and the error is more along the drainage network. Topographic index is used by different researchers considering different DEM grid spacing for their application at local and regional scale (Kumar et al. 2000; Wu et al. 2007). Grid spacing directly affects the calculation of upslope area as well as the topographic index (Quinn et al. 1995). Yong et al. (2009) analysed the effect of terrain smoothening and discretisation of DEM grid spacing on topographic index and found that smoothening effect is relatively higher in the relatively cliffy terrain while discretisation effect is dominant in flat areas. The effect of smoothening and discretisation were closely related to local terrain characteristics.

However, the assessment of the topographic index is very important because any variation in the topographic index calculation may affect the accuracy of its applications and outcome of the model prediction (Raaflaub and Collins 2006). It is also important to study the characteristics of topographic index in Indian landscape especially in Himalayan terrain. In this study an attempt has been made to evaluate the topographic index (TOPMODEL topographic index) in Shivalik Himalayan terrain considering DEM grid spacing and terrain ruggedness characteristics. The study analyse how the DEM grid spacing and terrain roughness affect the statistical properties and accuracy of topographic index.

\section{Study area}

Western part of Dehradun, India is taken as the study area which is geographically situated within $30^{\circ} 8^{\prime} 30^{\prime \prime}-30^{\circ} 27^{\prime} 3^{\prime \prime} \mathrm{N}$ and $77^{\circ} 43^{\prime} 2^{\prime \prime}-78^{\circ} 2^{\prime} 52^{\prime \prime} \mathrm{E}$ (figure 1a). It is situated in the tropical (Joshi et al. 2011) climatic region, although it varies from warm in summers to severely cold in winters, depending upon the season and the altitude of the specific location. The district being hilly, temperature variations due to difference in elevation are considerable. Summers (March-June) have maximum temperature of $35^{\circ} \mathrm{C}$ and minimum of $17^{\circ} \mathrm{C}$. Winters (December to February) have maximum of $22^{\circ} \mathrm{C}$ and minimum of about $3{ }^{\circ} \mathrm{C}$. During the monsoon season heavy rainfall occurs. The area receives an average annual rainfall of $2100 \mathrm{~mm}$. Most of the annual rainfall is received during the months from June to September. Significant relief variation is present in this area. Geomorphologically the area is characterized by hills and valleys. The lower middle part of the study area is highly

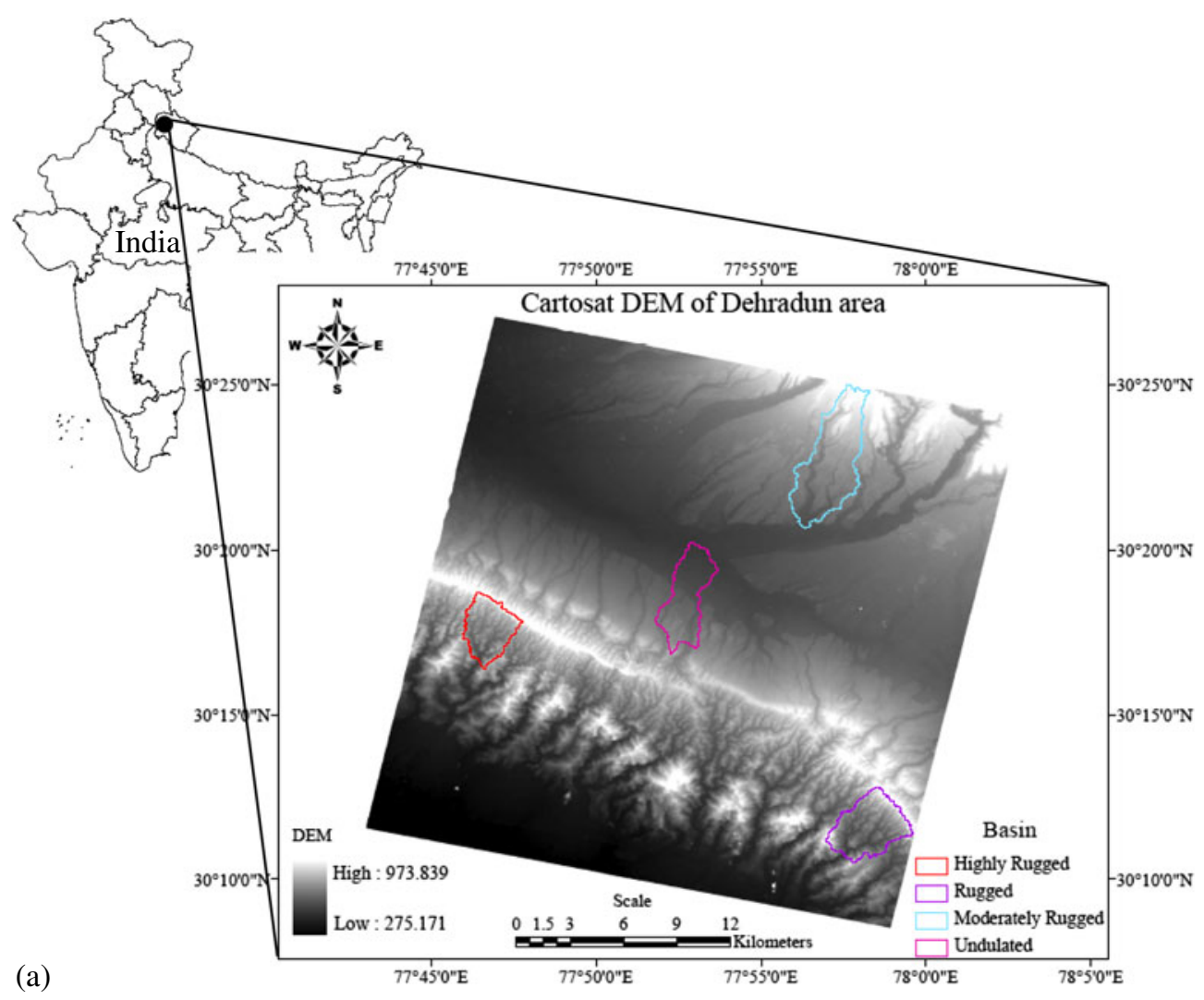

Figure 1(a). Cartosat DEM of study area and location of four drainage basins. 
rugged and mainly dominated by hills. Because of the high slope, the area is dissected by number of small rivers. The northern part of this area is the foot of the Mussoorie hill, having less terrain relief in comparison to the lower middle part. Central part of the terrain has little undulation but southern part is completely flat (figure 1a). Type of forest is mixed; within this Sal forest is dominating and density is medium to scattered. The hilly area is partially covered by the vegetation and very small vegetation cover is present along the river valley.

The present study analysed the impact of grid spacing and terrain roughness on the topographic index. Ruggedness implies the variation of slope in a terrain. It indicates the undulation or variation of relief. In order to identify the influence of terrain roughness, four small drainage basins of different relief characteristics (very rough to undulated) have selected and named as per the surface roughness; Highly rugged, Rugged, Moderately rugged and Undulated basin (figure 1b). For each basin, elevation versus distance curves were also plotted to understand their surface roughness characteristics by selecting two cross-sections ( $\mathrm{A}-\mathrm{B}$ and $\mathrm{C}-$ D) in the upper and lower portions of the basins (figure 1c). Initially the basins were identified from the Survey of India (SOI) toposheets and inspected during the field survey to segregate the basin as per relief characteristics. Qualitative and quantitative analysis carried out on the basin relief are discussed in section 4.1. The boundary of drainage basins were delineated using automatic catchment selection algorithm and the basin outlets were identified from SOI toposheet nos. 53J/3,4, 53F/15,16 at 1:50,000 scale. Information of the basins is given in table 1.

\section{Material and methods}

The methodology adopted in this study for assessment of the topographic index is given in sequential manner in figure 2 .

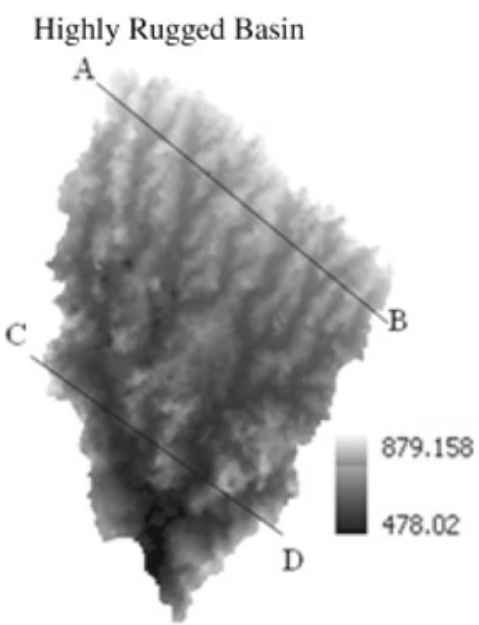

Moderately Rugged Basin

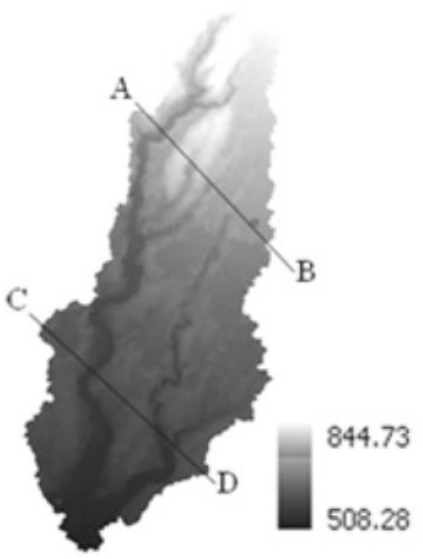

(b)

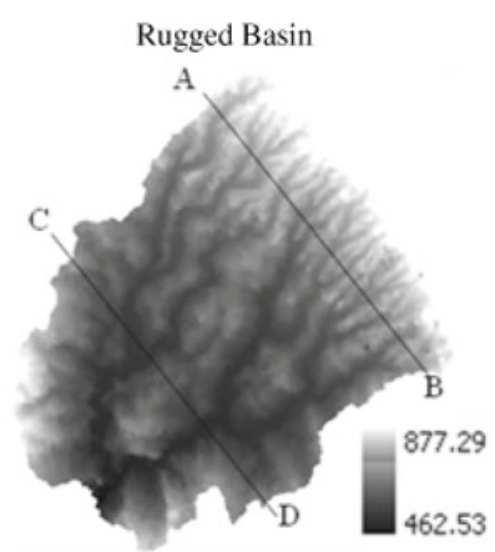

Undulated Basin

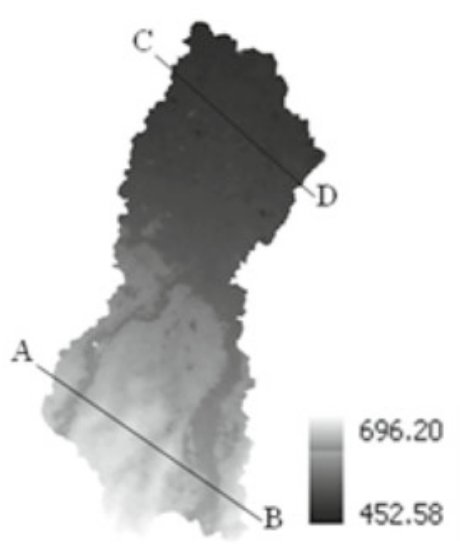

Figure 1(b). Enlargement of the basins showing the relief of terrain and altitudinal variations. 
Highly Rugged Basin

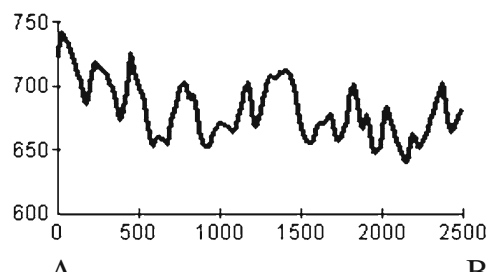

A

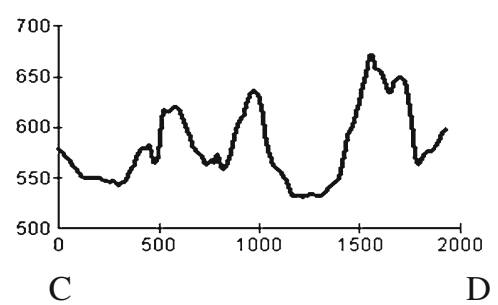

Moderately Rugged Basin
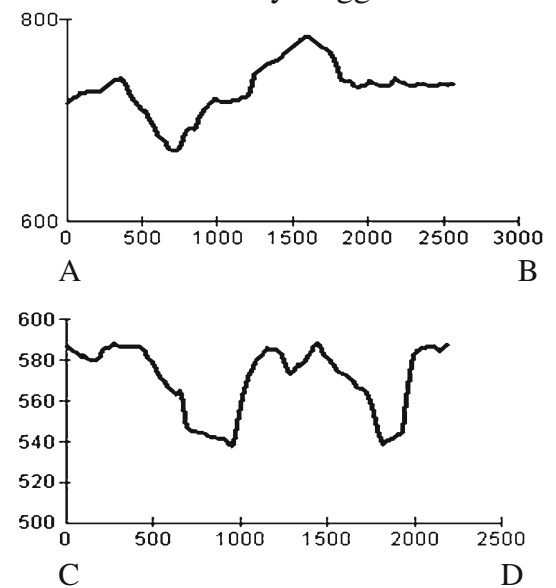

(c)
Rugged Basin

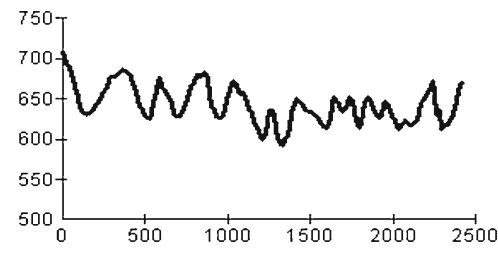

A

B

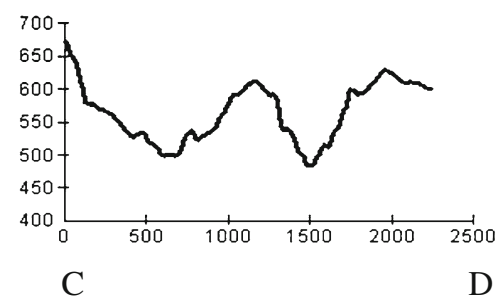

Undulated Basin
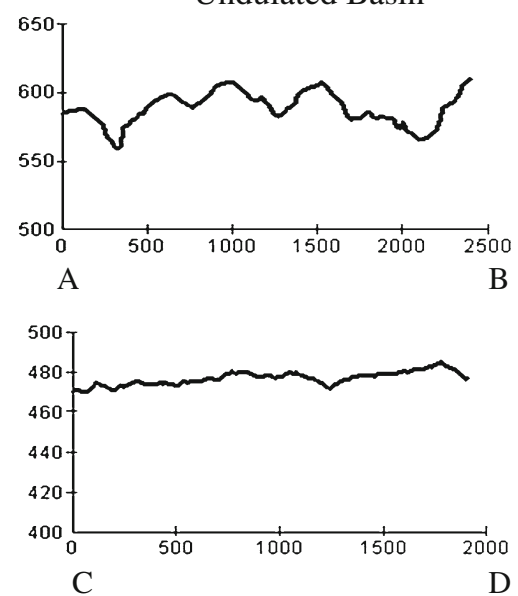

Figure 1(c). Cross section of upper and lower portion of each basin showing the terrain roughness characteristics.

Table 1. Basin characteristics.

\begin{tabular}{lccccc}
\hline Catchment type & Area $\left(\mathrm{km}^{2}\right)$ & Stream order & Outlet elevation $(\mathrm{m})$ & Outlet coordinate & Perimeter $(\mathrm{m})$ \\
\hline Highly rugged & 7.06 & 4 & 495 & $30^{\circ} 16^{\prime} 35^{\prime \prime} \mathrm{N}, 77^{\circ} 46^{\prime} 28^{\prime \prime} \mathrm{E}$ & 13551.84 \\
Rugged & 9.88 & 4 & 463 & $30^{\circ} 10^{\prime} 43^{\prime \prime} \mathrm{N}, 77^{\circ} 57^{\prime} 31^{\prime \prime} \mathrm{E}$ & 16058.05 \\
Moderately rugged & 15.97 & 5 & 454 & $30^{\circ} 20^{\prime} 39^{\prime \prime} \mathrm{N}, 77^{\circ} 56^{\prime} 21^{\prime \prime} \mathrm{E}$ & 25419.03 \\
Undulated & 9.13 & 4 & 442 & $30^{\circ} 20^{\prime} 10^{\prime \prime} \mathrm{N}, 77^{\circ} 52^{\prime} 50^{\prime \prime} \mathrm{E}$ & 19176.85 \\
\hline
\end{tabular}

\subsection{DEM generation}

High resolution (2.5 m) Cartosat-1 data was used in this study. Cartosat-1 satellite has a forward $(\mathrm{F})$ and aft $(\mathrm{A})$ panchromatic camera which gives the along track stereo, with a tilt of $+26^{\circ}$ and $-5^{\circ}$ respectively in flight direction (Baltsavias et al. 2007). Stereo imagery of 2 October 2005 (Path/Row - 0526/0258) was used for generation of DEM. DGPS (Differential Global Positioning System) survey was conducted in the Dehradun area and 20 well distributed GCPs (ground control points) over the scene were collected. Initially stereo block was oriented with RPCs (rational polynomial coefficients) which comes with the satellite data. Then GCPs were added in the stereo model to avoid the systematic error. 15 GCPs were used as control points and 5 GCPs were used as check points to orient the stereo model. LPS software, version 9.2 , has been used for the orientation of the stereo block. From the oriented stereo block, DEM at $10 \mathrm{~m}$ grid size has been generated with overall accuracy (RMSE) of 1.06 pixels and vertical check point accuracy of $1.11 \mathrm{~m}$ (RMSE). After that from the same block DEMs at grid size 30, 50, 90, 110 and $150 \mathrm{~m}$ were produced. 


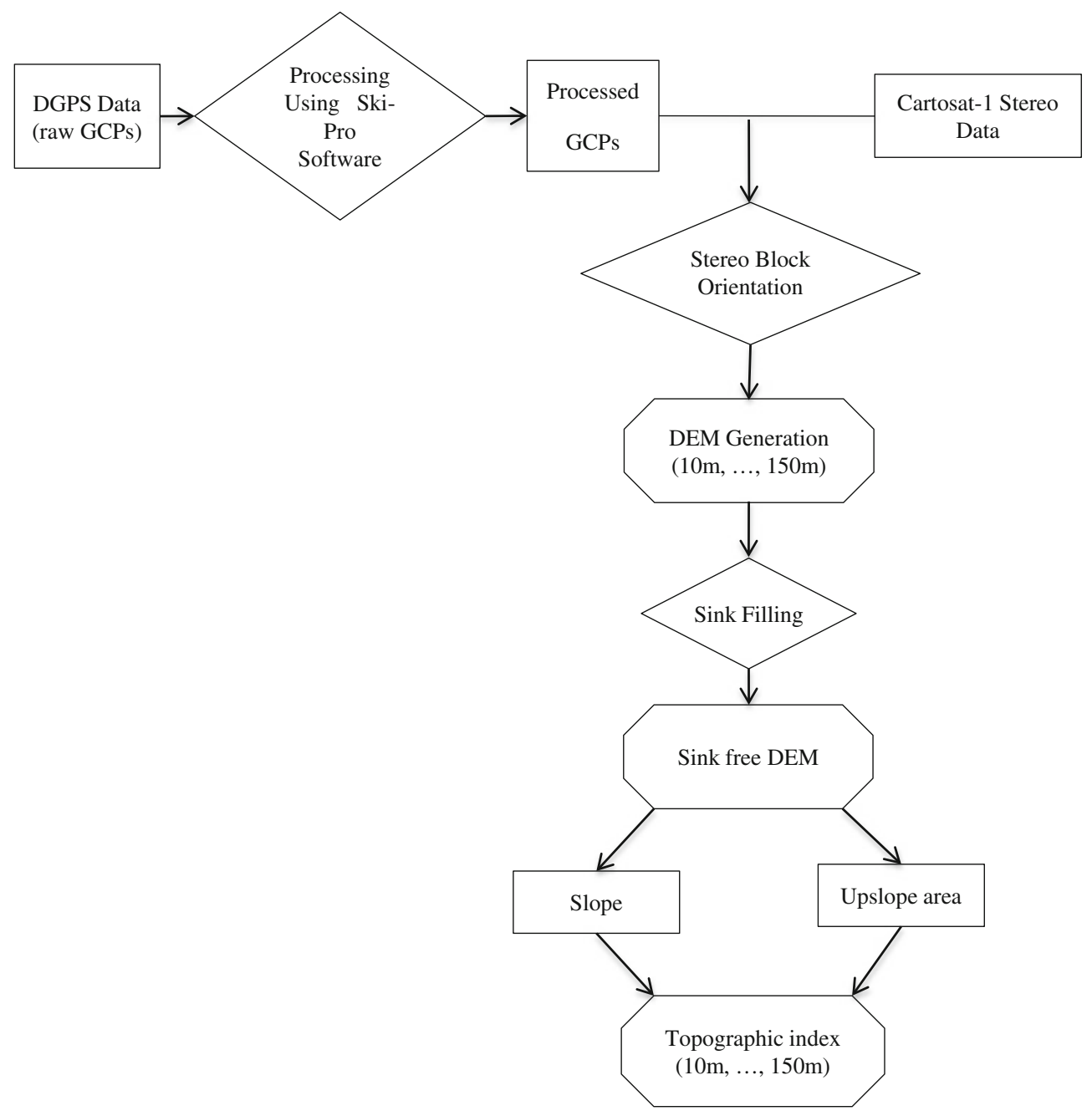

Figure 2. Flow diagram of DEM generation and calculation of topographic attributes.

\subsection{Sink filling and catchment delineation}

Presence of sink or artifacts is a common problem for extraction of drainage network using DEM. If the elevation value of surrounded cell is higher than a particular cell then the down slope flow path of that cell has been confined and the sink occur (Grimaldi et al. 2007; Wu et al. 2008). The sink can be real component of DEM or artifacts produced during the DEM generation process. It causes difficulties in hydrological calculation and need to be removed by increasing the values of cell in each sink by the value of cell with lowest value on sink boundary (Jenson and Domingue 1988). Sink filling was carried out for all DEMs before delineation of catchment and generation of terrain attribute. After the sink filling, drainage network was extracted with the help of flow direction and flow accumulation and finally the catchment was delineated.

\subsection{Computation of topographic index}

According to the algorithm $(\operatorname{Ln}(\alpha / \tan \beta))$, two parameters are needed to derive the topographic index; specific catchment area $(\alpha)$ and slope $(\tan \beta)$.

\subsubsection{Calculation of specific catchment area $(\alpha)$}

The calculation of specific catchment area requires the total area draining into each cell, i.e., upslope contributing area and 'contour length'. For a grid DEM 'contour length' is considered to be the grid spacing.

$$
\begin{aligned}
\operatorname{Upslope} \text { area }(\mathrm{A})= & (\text { No. of upslope cells }+1) \\
& \times(\text { grid cell area })
\end{aligned}
$$

Specific catchment area $(\alpha)=\mathrm{A} / \mathrm{L}$,

where $\mathrm{L}=$ grid spacing.

Various algorithms are used for the calculation of upslope contributing area. Among them single flow direction algorithm (SFD) and multiple flow direction algorithm (MFD) are most commonly used by the hydrologists for modelling. SFD method (Jenson and Domingue 1988) directs water flow from each grid cell to one of eight nearest neighbours 
based on steepest downslope direction (Wolock and McCabe 1995). Whereas MFD algorithm assumes that water flows from a cell to its entire downslope neighbours with weighting by slope (Quinn et al. 1991; Pan et al. 2004). SFD method is suitable for zone of convergent flow and well defined valleys, while MFD method is accurate for overland flow analysis in hill slope (Wu et al. 2008). In this study SFD algorithm was used for calculation of upslope area. The elevation of each grid cell was compared with the elevation of its octagonal neighbours and the steepest downslope direction was assigned to each cell.

\subsubsection{Calculation of slope $(\tan \beta)$}

At a given point on a surface, height value is $\mathrm{Z}=$ $\mathrm{f}(\mathrm{x}, \mathrm{y})$. The first derivative of elevation describes the rate of change of elevation, which is slope. Together, slope in $\mathrm{x}$ direction and slope in y direction (partial derivatives of $\mathrm{z}$ with respect to $\mathrm{x}$ and $\mathrm{y}$ directions), define gradient vector of the surface. The maximum slope can be determined by taking the norm of this vector. On a grid DEM, slope calculation is done using $3 \times 3$ moving window to derive finite differential. In this study, second order finite difference is used. Four closest neighbours (FCN) algorithm (Guth 1995; Raaflaub and Collins 2006) is used for computing the slope. It takes into account, two orthogonal components of slope, slope in $\mathrm{x}$ direction and slope in y direction. In other words, the algorithm used the four cardinal neighbours, i.e., north, south, east and west representing a second order finite difference relationship. This defines the steepness and downhill direction. The algorithm is described below:

$$
\begin{gathered}
\text { Slope }=\sqrt{\left(\frac{d z}{d x}\right)^{2}+\left(\frac{d z}{d y}\right)^{2}} \\
\frac{d z}{d x}=\frac{\left(z_{8}-z_{2}\right)}{2 g}, \frac{d z}{d y}=\frac{\left(z_{6}-z_{4}\right)}{2 g}
\end{gathered}
$$

where $d z$ is the difference in elevation value, $d x$ is the distance in $\mathrm{x}$ direction, $d y$ is the distance in $\mathrm{y}$ direction, $z_{2}, z_{4}, z_{6}, z_{8}$ are height value of $2^{\text {nd }}, 4^{\text {th }}$, $6^{\text {th }}$ and $8^{\text {th }}$ neighbouring cells of the central pixel of the $3 \times 3$ window.

\section{Results and discussion}

\subsection{Basin relief characterization}

Present study concentrated to identify the impact of terrain roughness on topographic index. Hence, the relief characteristics of the basins were analysed. The roughness characteristics of the basins were segregated based on both qualitative and quantitative analysis. For qualitative analysis, cross profile of the surface taken from $10 \mathrm{~m}$ grid spacing DEM and the visual interpretation of contour pattern of SOI toposheet (1:50,000 scale, $20 \mathrm{~m}$ contour interval) were studied. Contour pattern is one of the indicators of the terrain roughness. It was found that in highly rugged and rugged basins, the spacing of the contours was very less, indicating high slope. Also the contour lines were highly curved implying highly varied terrain relief. Two cross sections of each basin, shown as A-B and $\mathrm{C}-\mathrm{D}$ in figure $1(\mathrm{~b})$, were taken in upper and lower parts of each catchment, which reflected the variation of relief in the study area. As shown in figure 1(c), the change of elevation with respect to distance was very high in highly rugged and rugged basin. Most of the areas of these two basins were situated above $500 \mathrm{~m}$ elevation and the area was highly dissected. The roughness was more in the upper catchment. The relief of the moderately rugged and undulated basins were very low and less dissected because of the few drainage line. The relative relief of the entire profile was much lower compared to rough terrain.

The quantitative analysis of the basin roughness was carried out based on three parameters:

- Surface slope,

- Curvature, and

- Topographic roughness index (TRI).

Roughness of the terrain can be identified by the surface slope (change of elevation). In rough terrain, difference in elevation of an area with its neighbourhood is high and thus rugged terrain is having high slope. Slope map was generated for all basins and classified into eight classes of $10^{\circ}$ equal interval. Percentage of area within each slope class to total area of the basin was calculated and plotted as shown in figure 3. It was found that more than $80 \%$ area of undulated basin, $63 \%$ of moderately rugged basins were having less than $10^{\circ}$ slopes, while rugged and highly rugged basins have more area in $20^{\circ}-30^{\circ}$ slope category.

But slope cannot be the absolute measure of the terrain roughness because in a highly inclined terrain, the slope of the area may be high and that does not mean the terrain is rugged. Ruggedness implies the variation of slope in a terrain which is indicated by curvature. It determines the rate of change of slope along the direction at that point. A positive curvature indicates that the surface is upwardly convex and negative curvature indicates that the surface is upwardly concave at that cell. A value of zero indicates that the surface is flat. Profile curvature of all the four basins were calculated and divided into eight classes. Percentage of 
area within each class to total area of the basins were calculated and plotted. According to the classification, the area having curvature value within -0.02 to 0.02 could be considered as flat terrain. It was found (as shown in figure 4) that more than $80 \%$ area of undulated basin was falling under this category. In the highly rugged and rugged basins, the change of slope was more in comparison to undulated basin and thus curvature was high.

TRI was computed (Moreno et al. 2005) to segregate the basins as per terrain relief. TRI represents the amount of elevation difference among the adjacent cells of a DEM. The process computes the differences in elevation value from central cell to its eight neighbours. TRI is derived by taking the rootmean-square of the elevation differences. It reflects average elevation change between any point on a grid and its surrounding areas. The mean value of TRI was taken into consideration and it was found to be $5.34,4.61,1.87$ and 1.26 for highly rugged, rugged, moderately rugged and undulated basins, respectively.

\subsection{Effect of DEM grid spacing and terrain roughness on spatial autocorrelation of the topographic index}

Topographic index was computed for all four drainage basins from low to high $(10-150 \mathrm{~m})$ grid spacing Cartosat DEMs. It was found that computation of the topographic index was affected by grid spacing of DEM. For higher grid spacing, the topographic index of a catchment reflected only higher order stream and was tend to ignore the existence of low order channels (figure 5). Due to the high smoothing effect at larger spacing, small channels were 'hidden' within the grid cells. In smaller grid spacing, the spatial pattern of topographic index matched with the drainage network. Near the drainage network, topographic index values were high and it declined away from the drainage lines. This reflected the spatial correlation of the topographic index with respect to its spatial location, which was referred as spatial autocorrelation. But towards the large grid spacing, spatial

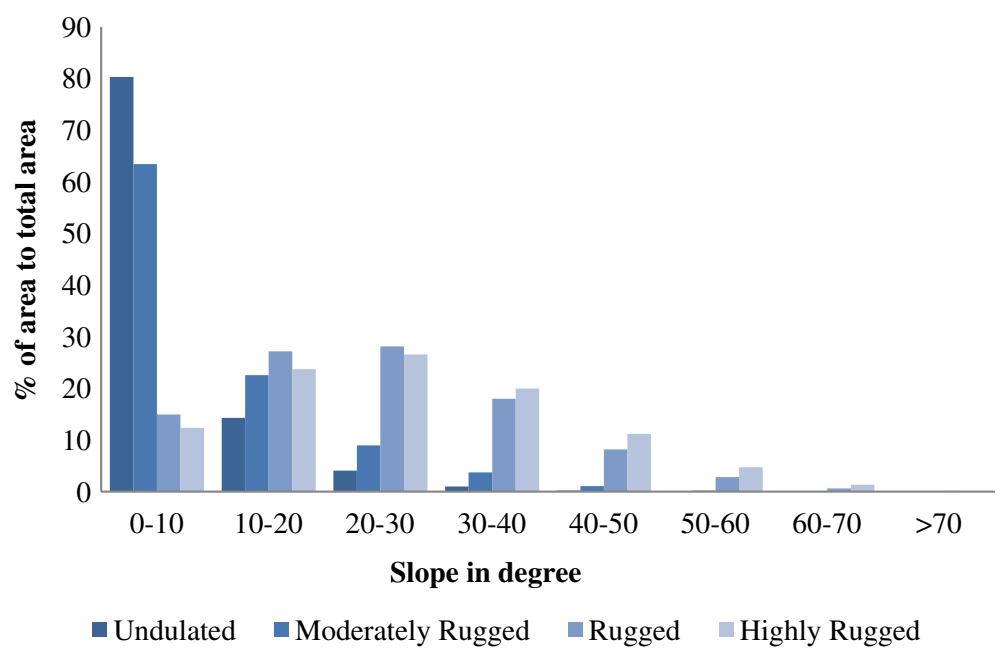

Figure 3. Slope $-\%$ area relationship for the basins.

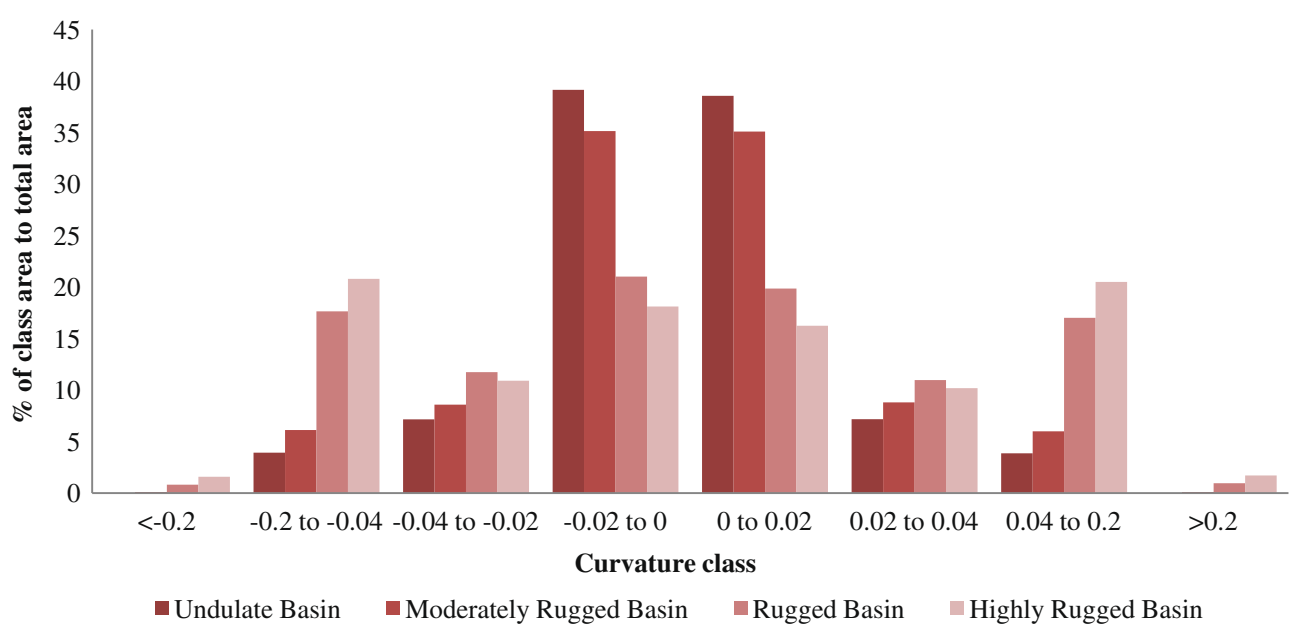

Figure 4. Profile curvature of the basins. 

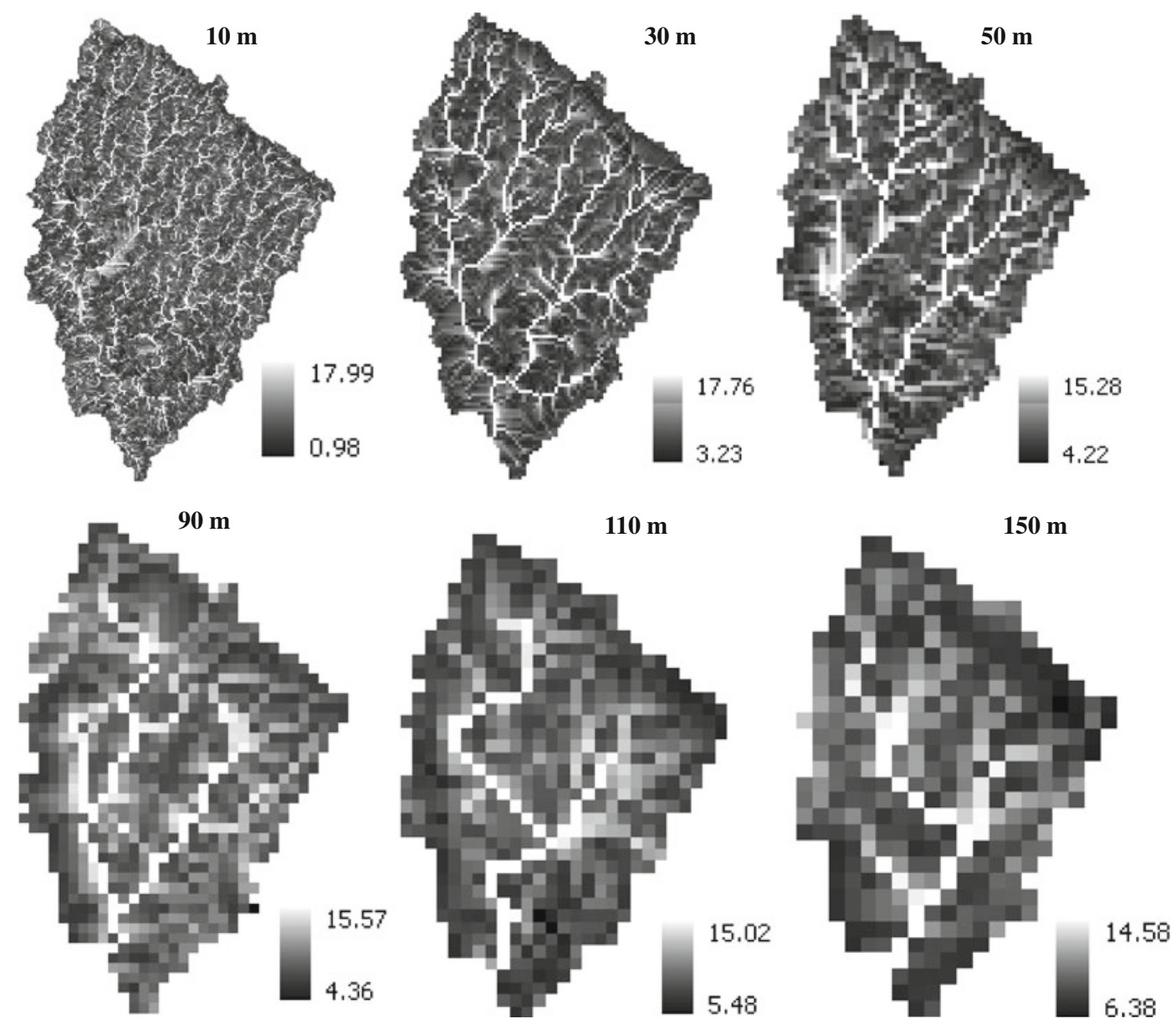

Figure 5. Topographic index computed from 10 to $150 \mathrm{~m}$ grid spacing of DEM for highly rugged basin. It shows the high value of topographic index near the drainage line.

autocorrelation of the topographic index was violated. Spatial autocorrelation index was investigated in terms of Moran's I index (Dale and Fortin 2002; Cai and Wang 2006; Shortridge 2007) for the topographic index surfaces at different grid spacing (figure 6). The value of Moran's I index varied from +1 to -1 . Positive value indicated that the objects were highly correlated or clustered whereas negative value indicated the dissimilarity (Goodchild 1986). It showed that Moran's I value of topographic index surfaces declined with increase in the grid spacing which signified that pattern of the topographic index surface was changing and becoming more random with the increase of grid spacing.

\subsection{Effect of DEM grid spacing and terrain roughness on the topographic index statistics}

It was found that grid spacing of DEM has great impact on the derivation of the topographic index. The statistics of topographic index surface (table 2) for all basins have changed with the grid spacing. Minimum value of the topographic index surface has increased and the maximum value decreased with higher grid spacing. The range and standard deviation values were also found to be less when the topographic index was computed from DEMs with larger grid spacing. It was also found that grid spacing has significant impact on the mean of topographic index. Mean of topographic index was continuously increasing with increase in grid spacing (figure 7). Mean of topographic index plot showed that the overall trend of the curves was parabolic in nature, but up to $90 \mathrm{~m}$ resolution this trend was found close to linear function. It was observed that mean of topographic index was more in the undulated basin in comparison to rugged basin, because the smooth area was having more potential to be saturated due to lower ground slope and the potentiality of soil saturation and topographic index both would be higher. If the grid spacing of DEM was increased, the representation of surface became smoother. A smooth surface has high value of topographic index. But the mean elevation (figure 8) did not change with increase in spacing which showed the behavioural 


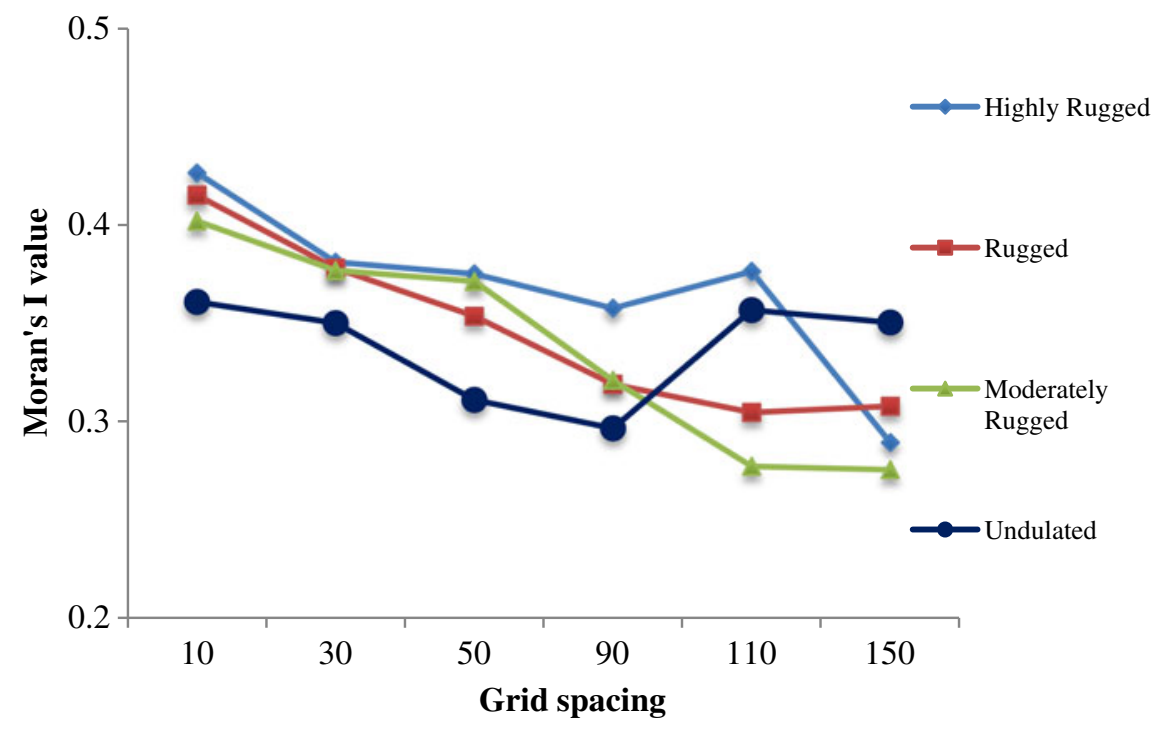

Figure 6. Moran's I index calculated for topographic index surfaces at various grid spacing.

Table 2. Statistics of different grid spacing topographic index surfaces.

\begin{tabular}{|c|c|c|c|c|c|c|}
\hline \multirow[b]{2}{*}{ Statistics } & \multicolumn{6}{|c|}{ Grid spacing } \\
\hline & $10 \mathrm{~m}$ & $30 \mathrm{~m}$ & $50 \mathrm{~m}$ & $90 \mathrm{~m}$ & $110 \mathrm{~m}$ & $150 \mathrm{~m}$ \\
\hline \multicolumn{7}{|l|}{ Highly rugged basin } \\
\hline Minimum & 0.98 & 3.23 & 3.93 & 4.36 & 5.48 & 6.38 \\
\hline Maximum & 17.99 & 17.76 & 15.28 & 15.57 & 15.02 & 14.58 \\
\hline Mean & 4.56 & 6.09 & 7.00 & 15.57 & 8.14 & 8.68 \\
\hline Standard deviation & 2.05 & 1.93 & 1.82 & 1.71 & 1.73 & 1.58 \\
\hline \multicolumn{7}{|l|}{ Rugged basin } \\
\hline Minimum & 0.63 & 0.85 & 1.89 & 2.75 & 3.16 & 3.81 \\
\hline Maximum & 19.63 & 16.55 & 15.57 & 15.23 & 15.33 & 15.58 \\
\hline Mean & 4.71 & 6.23 & 7.06 & 7.93 & 8.17 & 8.6 \\
\hline Standard deviation & 2.04 & 1.89 & 1.74 & 1.72 & 1.68 & 1.66 \\
\hline \multicolumn{7}{|c|}{ Moderately rugged basin } \\
\hline Minimum & 0.8 & 1.54 & 2.16 & 2.67 & 3.08 & 3.7 \\
\hline Maximum & 20.66 & 18.74 & 19.71 & 17.2 & 17.09 & 15.94 \\
\hline Mean & 5.84 & 7.42 & 8.15 & 8.97 & 9.24 & 9.65 \\
\hline Standard deviation & 2.11 & 2.1 & 2 & 1.89 & 1.79 & 1.73 \\
\hline \multicolumn{7}{|l|}{ Undulated basin } \\
\hline Minimum & 1.08 & 4.65 & 5.53 & 6.77 & 6.68 & 7.68 \\
\hline Maximum & 20.94 & 17.92 & 17.25 & 15.27 & 16.34 & 15.09 \\
\hline Mean & 6.2 & 7.9 & 8.59 & 9.3 & 9.72 & 9.99 \\
\hline Standard deviation & 2.12 & 1.95 & 1.96 & 1.73 & 1.99 & 1.56 \\
\hline
\end{tabular}

dissimilarity of DEM and topographic index. Computation of the topographic index depends on specific catchment area and slope. It is directly proportional to specific catchment area and inversely proportional to the slope. It was observed that (figure 9) specific catchment area increased with grid spacing for all basins which led to overestimation of the topographic index.

The mean of slope curve (figure 10) has decreased with increase in grid spacing due to smoothening of the surface and the smoothening effect was more pronounced in the rough terrain. With the increase of grid spacing from 30 to $90 \mathrm{~m}$, the mean of slope of highly rugged and rugged basins decreased 2 times and 1.9 times, respectively but 1.6 times in undulated basin (table 3 ). The rate of change in mean of slope curve (figure 8) was much higher for rough terrain up to $90 \mathrm{~m}$ grid spacing and after that it was stabilized. The relationship (figure 11) between mean of slope and 


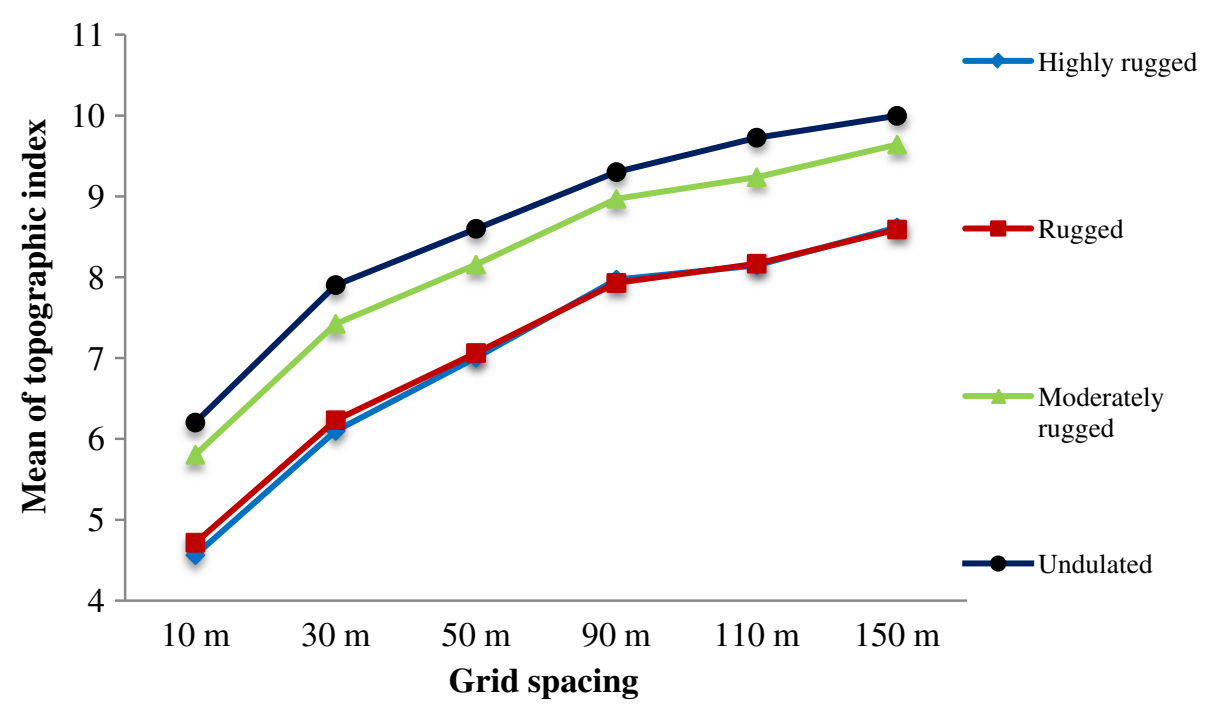

Figure 7. Mean of topographic index with DEM grid spacing.

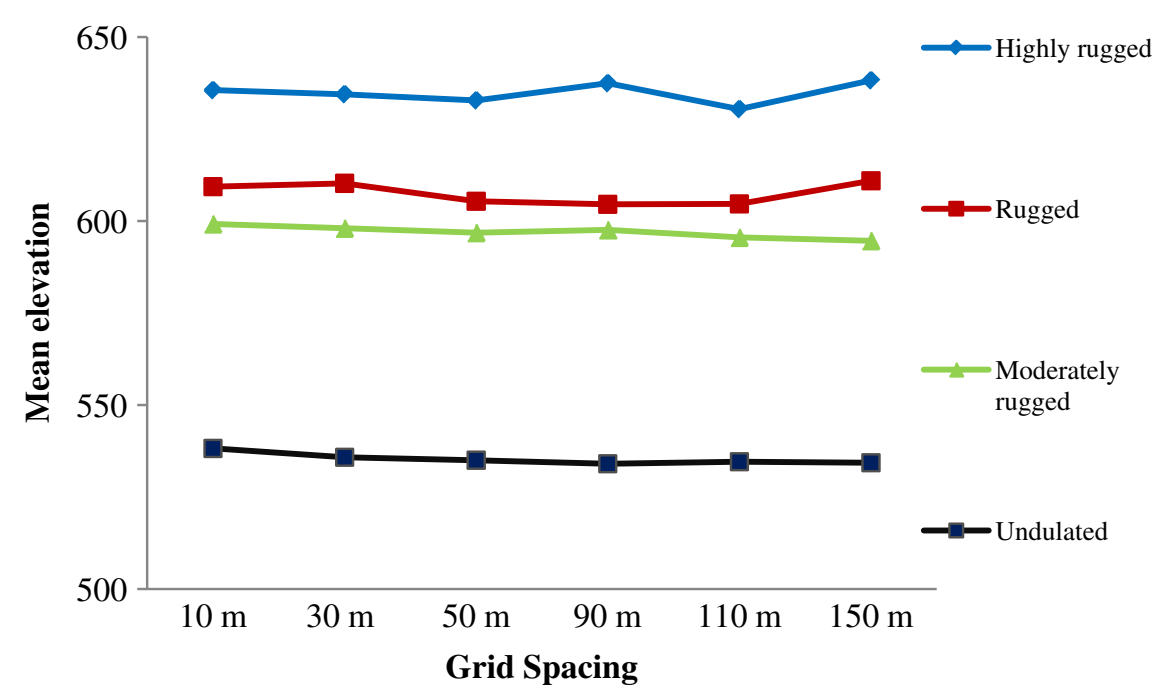

Figure 8. Mean elevation of DEM of four basins shows that although in the larger grid spacing the representation of the terrain become smooth, the mean elevation is constant.

mean of topographic index was also observed as negative in nature and highly correlated; the $R^{2}$ value was 0.80 . It signified that with the higher grid spacing of DEM, the representation of surface slope decreased causing the increase in the mean of topographic index.

In order to find out the influence of terrain relief on the mean of topographic index, related to grid spacing, linear regression has been generated considering grid spacing of 10-150 m (independent) and mean of topographic index (dependent) for all drainage basins (figure 12). $R^{2}$ values ranging from 0.87 to 0.85 were obtained, which were statistically significant. The gradient of the regression lines for highly rugged, rugged and moderately rugged basins were more inclined than undulate basin, which suggested that the computation of the topographic index in the higher grid spacing was more affected in rough terrain in comparison to smooth terrain. If the grid spacing increased, the terrain model became smoother. A smoother surface implied a larger mean of topographic index. The smoothing effect of increasing the DEM spacing was stronger for the most rugged terrain. But the undulated terrain was less influenced by grid spacing in terms of smoothing effect. Hence, it could be said that the influence of grid spacing on the topographic index deterioration depended on terrain variability. The effect was larger in the more rugged terrain in comparison to moderate and undulated terrain which was also observed in the spatial autocorrelation. 


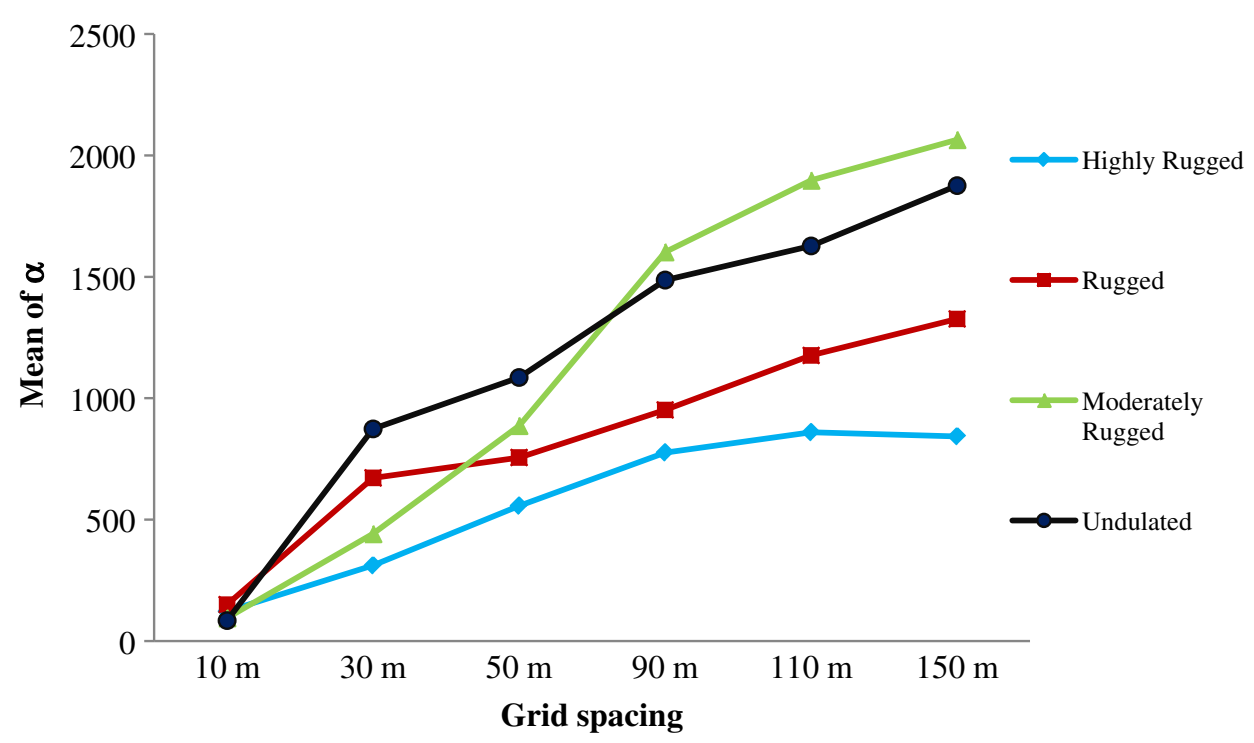

Figure 9. Mean of specific catchment area computed for all the basins.

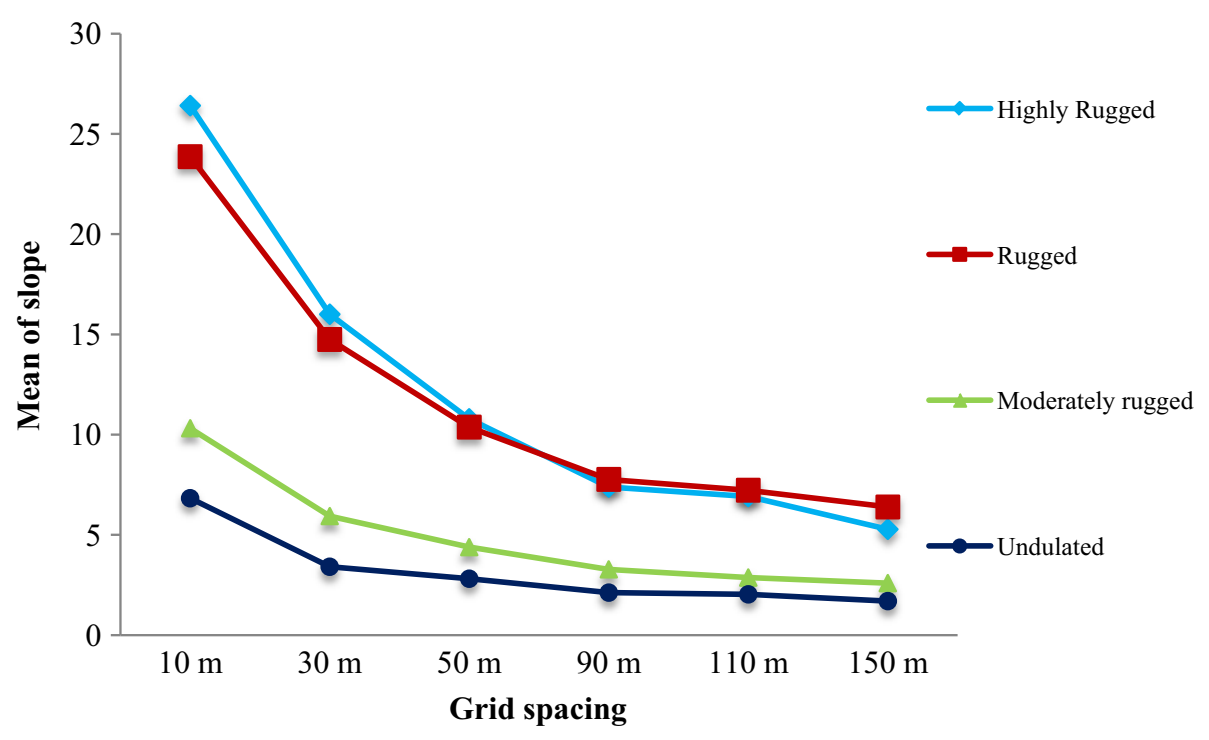

Figure 10. Mean of slope calculated for all the basins. Slope value decrease $10 \mathrm{~m}$ grid spacing to $90 \mathrm{~m}$ grid spacing and after that stabilized.

Table 3. Mean of slope.

\begin{tabular}{lrrrrrr}
\hline Basin/resolution & $10 \mathrm{~m}$ & $30 \mathrm{~m}$ & $50 \mathrm{~m}$ & $90 \mathrm{~m}$ & $110 \mathrm{~m}$ & $150 \mathrm{~m}$ \\
\hline Highly rugged & 26.41 & 16.01 & 10.79 & 7.39 & 6.91 & 5.28 \\
Rugged & 23.87 & 14.74 & 10.37 & 7.76 & 7.23 & 6.39 \\
Moderately rugged & 10.32 & 5.93 & 4.39 & 3.28 & 2.87 & 2.59 \\
Undulated & 6.83 & 3.40 & 2.81 & 2.12 & 2.03 & 1.70 \\
\hline
\end{tabular}

\subsection{Effect of DEM grid spacing and terrain} roughness on accuracy of the topographic index

DEM represents the surface of the Earth. Higher the resolution, the representation of the Earth surface is much more detailed. Because of this reason, accuracy of the topographic index is evaluated in terms of interscale comparison to find out the behaviour of the topographic index surface computed from DEMs with different grid spacing. According to Zhang and Montgomery (1994), $10 \mathrm{~m}$ grid size topographic index provided a substantial improvement over 30 and $90 \mathrm{~m}$ data, but 2 or $4 \mathrm{~m}$ data provided only marginal additional improvement for the moderate to steep gradient terrain. Brasington and Richards (1998) investigated that the efficiency of TOPMODEL prediction decreased with respect to grid size of the topographic index. As the DEM grid spacing increased, the mean of topographic index and predicted overland flow also increased, and the efficiency of model reduced. 


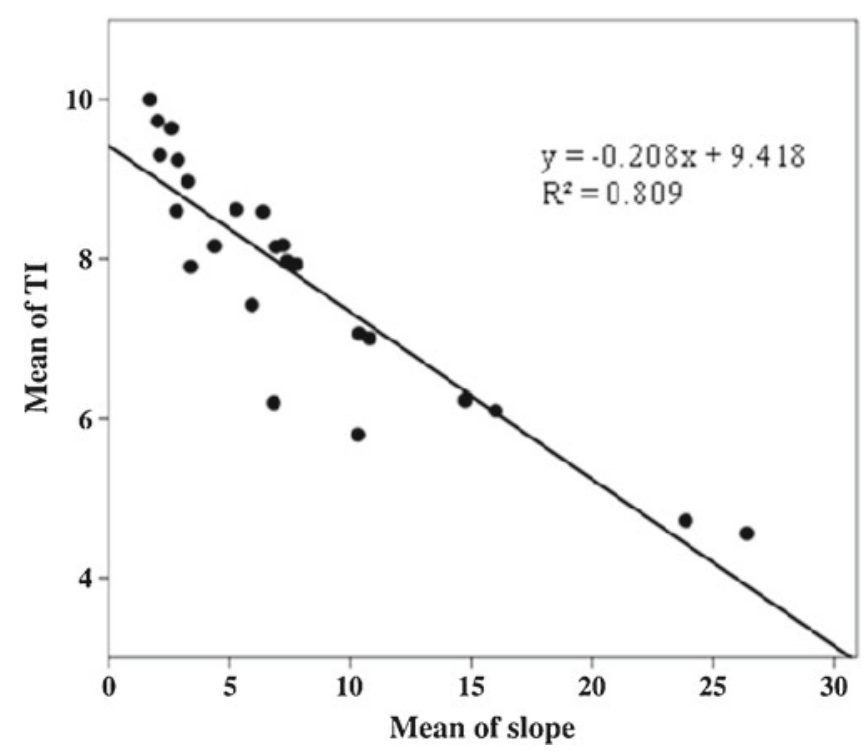

Figure 11. Relationship between slope and topographic index.

The previous study has also revealed that to simulate the geomorphic and hydrological processes, $10 \mathrm{~m}$ grid size datasets made a rational compromise between increasing grid spacing and data volume. Hence, the topographic index compute from $10 \mathrm{~m}$ resolution DEM has been taken as 'reference surface' for interscale comparison because it described the near real ground surface representation. From the Cartosat-1 stereo data, the optimal resolution DEM that could be achieved, is $10 \mathrm{~m}$ to avoid the blunders and blind valley which result during the image matching process while generating the DEM at high resolution (better than $10 \mathrm{~m}$ ). Topographic indices derived from different grid spacing DEMs (30, 50, 90, 110 and $150 \mathrm{~m})$ were compared with the 'reference data'. The specific grid spacing $(30,50,90,110$ and $150 \mathrm{~m})$ topographic index surfaces were evaluated in this study because of their availability and uses in the hydrological study. ASTER DEM of $30 \mathrm{~m}$ grid spacing is available for the entire globe and SRTM $30 \mathrm{~m}$ (1 arcsec)

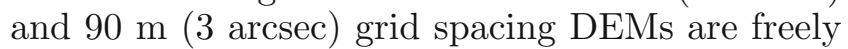
available for the USA and whole world. DEMs with 50, 110 and $150 \mathrm{~m}$ resolution can be generated from contours of any topographic map using the interpolation techniques.

The evaluation of topographic index was done in terms of RMSE (root mean square error) and ME (mean error).

$$
\begin{aligned}
\mathrm{RMSE} & =\left[n^{-1} \sum_{i=1}^{n}\left(T I_{\mathrm{ref} 10}-T I\right)^{2}\right]^{1 / 2} \\
\mathrm{ME} & =\left[n^{-1} \sum_{i=1}^{n}\left(T I-T I_{\text {ref } 10}\right)\right]
\end{aligned}
$$

where $T I_{\text {ref10 }}$ is reference topographic index at $10 \mathrm{~m}$ grid spacing and $T I$ is topographic index at different resolution.

The RMSE gives a measure of accuracy. It exhibits how far, on average; the observed values are from the assumed true value. The ME tells us

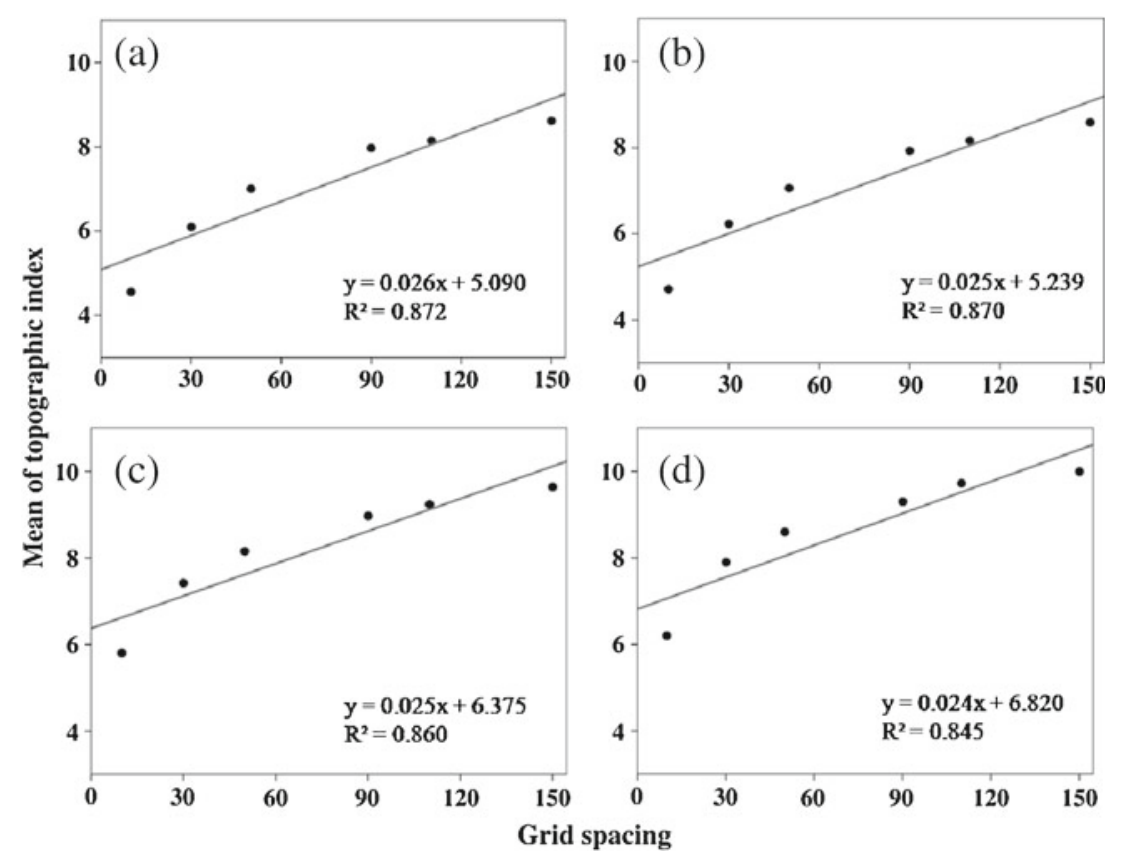

Figure 12. Relationship between grid spacing and mean of topographic index. 


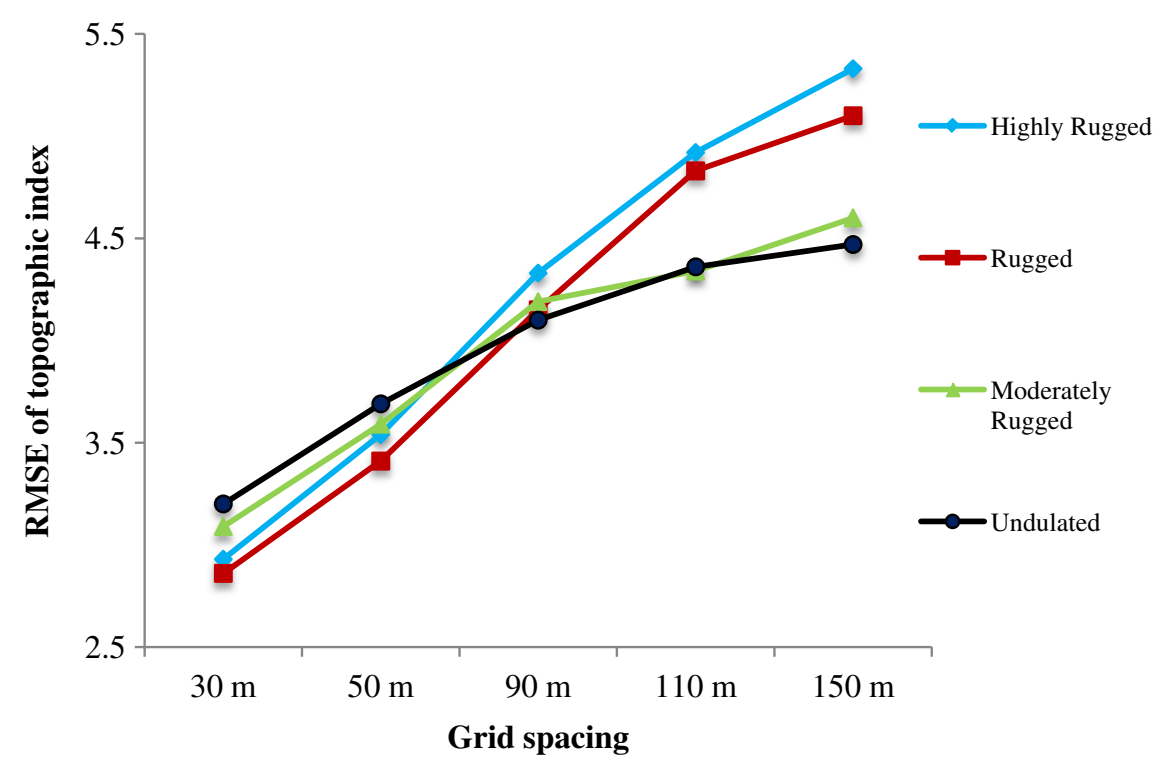

Figure 13. RMSE of topographic index with respect to change in grid spacing.

Table 4. RMSE of topographic index.

\begin{tabular}{lccccc}
\hline Basin/resolution & $30 \mathrm{~m}$ & $50 \mathrm{~m}$ & $90 \mathrm{~m}$ & $110 \mathrm{~m}$ & $150 \mathrm{~m}$ \\
\hline Highly rugged & 2.93 & 3.54 & 4.33 & 4.92 & 5.33 \\
Rugged & 2.86 & 3.41 & 4.15 & 4.83 & 5.10 \\
Moderately rugged & 3.09 & 3.59 & 4.19 & 4.34 & 4.60 \\
Undulated & 3.20 & 3.69 & 4.10 & 4.36 & 4.47 \\
\hline
\end{tabular}

whether a set of measurements consistently underestimate (negative ME) or overestimate (positive $\mathrm{ME}$ ) the true value. The RMSE is a single quantity characterizing the error surface, and the mean error reflects the bias of the error surface. RMSE and $\mathrm{ME}$ were computed by finding the difference between the reference topographic index and the topographic index at larger grid spacing (30, 50, 90, 110 and $150 \mathrm{~m}$ ). Topographic index surface at larger grid spacing was up-sampled into $10 \mathrm{~m}$ surface and compared with the reference topographic index surface to compute the RMSE and ME.

It has been observed that accuracy curve (RMSE) of the topographic index surface (figure 13) was increasing with the increase in grid spacing. In the finer grid spacing $(30 \mathrm{~m}$ and $50 \mathrm{~m}$ ) RMSE of the topographic index surface was higher in smooth terrain (undulated basin), but with the increase in grid spacing the topographic index surface of rough terrain became more erroneous. The RMSE range (table 4) of highly rugged and rugged basins (2.40 and 2.24) were higher in comparison with moderately rugged and undulated basins (1.27 and 1.51). The RMSE curve of the topographic index surface increased more rapidly up to $90 \mathrm{~m}$ resolution and after that rate of change was lower. This was mainly because varying
Table 5. Mean error of topographic index.

\begin{tabular}{lccccc}
\hline Basin/resolution & $30 \mathrm{~m}$ & $50 \mathrm{~m}$ & $90 \mathrm{~m}$ & $110 \mathrm{~m}$ & $150 \mathrm{~m}$ \\
\hline Highly rugged & 1.55 & 2.47 & 3.48 & 3.68 & 4.21 \\
Rugged & 1.52 & 2.37 & 3.27 & 3.52 & 3.96 \\
Moderately rugged & 1.58 & 2.33 & 3.16 & 3.42 & 3.85 \\
Undulated & 1.71 & 2.41 & 3.12 & 3.58 & 3.78 \\
\hline
\end{tabular}

degree of smoothening occurred in larger grid spacing DEMs.

The mean error (table 5) has also increased with increase in grid spacing indicating the overestimation of the topographic index value, as shown in figure 14. It was initially higher in undulated basin in comparison to highly rugged and rugged basins. Steepness of the ME curve was high up to $90 \mathrm{~m}$ grid spacing and after that the rate of change was lower. In higher grid spacing, the representation of the surface slope was smooth and a smooth surface led to high value of the topographic index. It was also observed that in larger grid spacing, the topographic index surface of the highly rugged and rugged basins were more affected by overestimation.

In order to find out the effect of terrain roughness on the topographic index accuracy, RMSE of the topographic index surface was plotted with respect to grid spacing and the linear regression line was fitted. It was found that slope of the regression line (figure 15) was more steep in highly rugged and rugged terrain in comparison with undulated terrain which indicated that the topographic index accuracy was influenced by the terrain roughness.

Mean of topographic index has increased with grid spacing, thus the RMSE of topographic index 


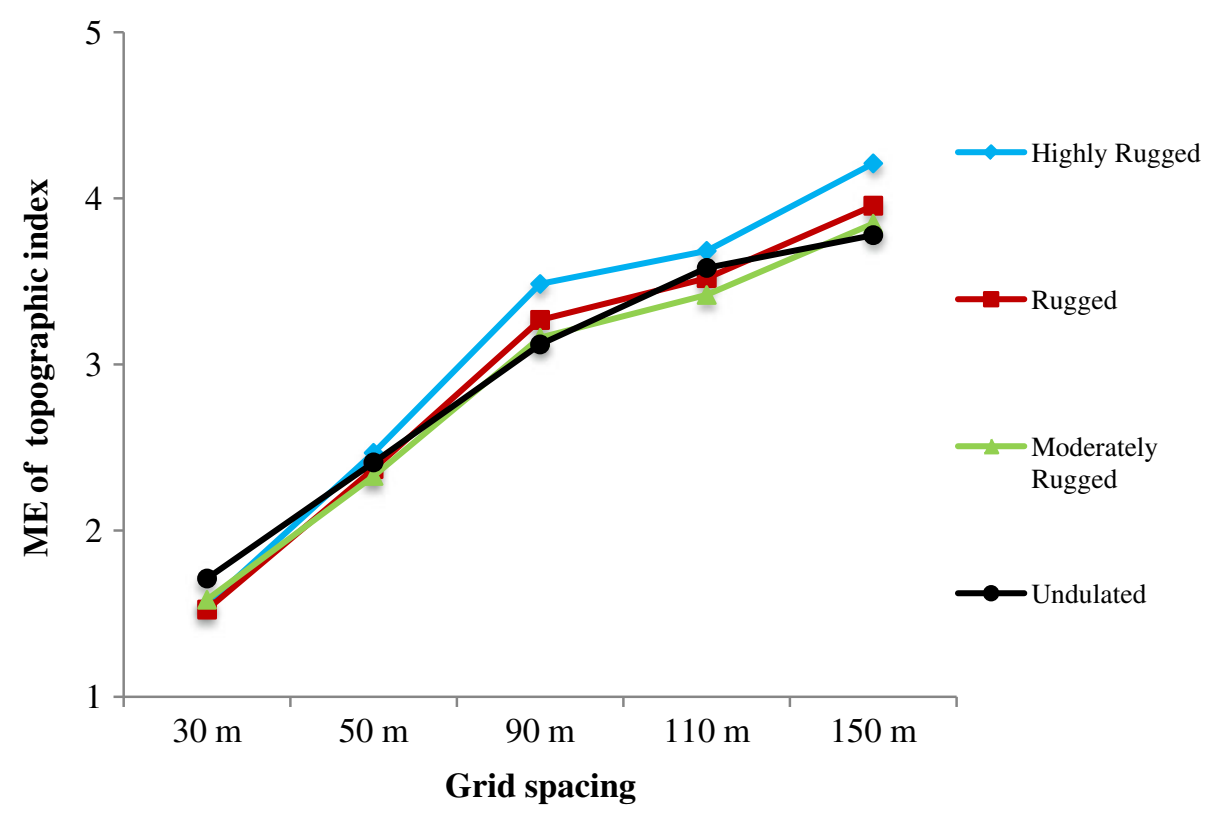

Figure 14. Mean error of topographic index with respect to change in grid spacing.

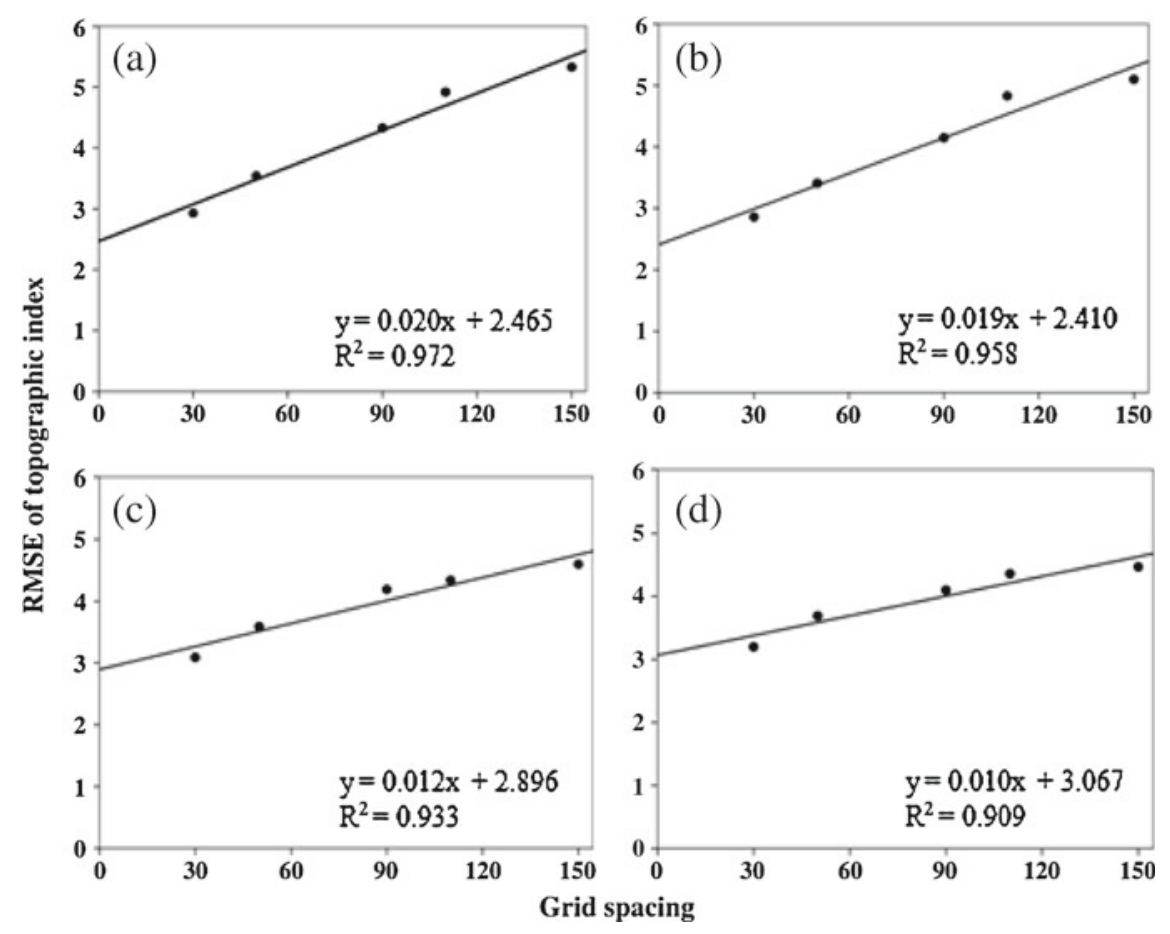

Figure 15. Relationship between grid spacing and RMSE of topographic index.

surface has also increased. Therefore, it was necessary to find out whether the dispersion of the topographic index also increased with grid spacing or not. In order to find this, RMSE (table 6) has been computed by subtracting the mean from each topographic index surface (standard error). Curve of the standard error showed that the 'dispersion RMSE' of the topographic index increased
Table 6. Standard error of topographic index.

\begin{tabular}{lccccc}
\hline Basin/resolution & $30 \mathrm{~m}$ & $50 \mathrm{~m}$ & $90 \mathrm{~m}$ & $110 \mathrm{~m}$ & $150 \mathrm{~m}$ \\
\hline Highly rugged & 2.48 & 2.54 & 2.57 & 2.61 & 2.55 \\
Rugged & 2.43 & 2.46 & 2.55 & 2.52 & 2.54 \\
Moderately rugged & 2.66 & 2.73 & 2.75 & 2.68 & 2.63 \\
Undulated & 2.70 & 2.79 & 2.65 & 2.83 & 2.57 \\
\hline
\end{tabular}




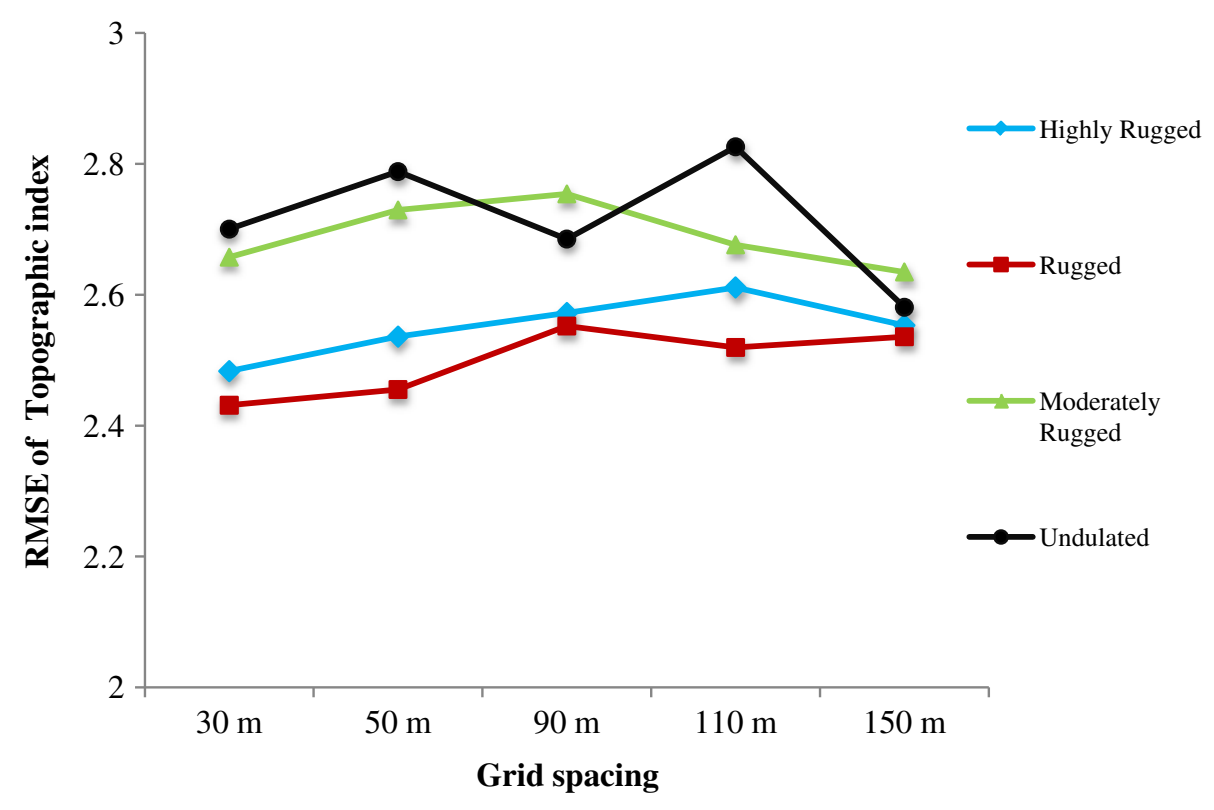

Figure 16. Dispersion accuracy of topographic index calculated for all basins at various grid spacing.

very slowly up to $90 \mathrm{~m}$ grid spacing and after that it decreased (figure 16). This observation again supported the finding that terrain roughness was a relevant terrain characteristic for the topographic index accuracy and increasing mean was the prime deterioration factor of the topographic index.

\section{Conclusions}

The present study evaluates topographic index in the tropical climatic region considering four watersheds with different relief characteristics, located in Himalayan terrain. The results achieved from the statistical analysis reveal that grid spacing of DEM influences the calculation of topographic index. The statistics (minimum, maximum, mean and standard deviation) of topographic index changes when computed from larger spacing DEMs. Representation of the ground surface is smooth in larger spacing DEM and calculation of topographic index value is higher. The mean of topographic index surface is continuously increasing with higher grid spacing DEMs and the trend is close to linear function up to $90 \mathrm{~m}$ grid size. The mean is higher in the undulated basin than highly rugged and rugged basin because of the inverse relationship between surface slope and topographic index. The mean of topographic index is highly $\left(R^{2}\right.$ is 0.809$)$ correlated with the mean of slope which implies the influence slope on the calculation of topographic index. It is also found that mean of topographic index is more affected in the rough terrain in larger grid spacing.
The behaviour of the DEM and topographic index is different when increasing the grid spacing. The mean of topographic index shows an increasing trend when calculated from coarse spacing DEMs but the mean elevation remains constant irrespective of grid size and terrain roughness. The spatial autocorrelation of topographic index surface declines when computed from larger spacing DEMs. The small channels are invisible within the coarse grid and the pattern of the surface is changing.

Analyzing the accuracy of the topographic index, the study found that grid spacing and terrain roughness affect the calculation of topographic index. In the rough terrain, the accuracy of the topographic index is violated while moving towards larger grid spacing. RMSE of topographic index surface is 2.93 at $30 \mathrm{~m}$ grid spacing which increases to 5.33 at $150 \mathrm{~m}$ grid spacing in highly rugged basin. But in undulated basin, the RMSE varies from 3.20 to 4.47 when the grid spacing is increased from 30 to $150 \mathrm{~m}$. Higher the grid spacing of a DEM, calculated slope is less and the topographic index is overestimated. The overestimation of topographic index is higher in the rough terrain which is due to terrain relief. Terrain relief determines the slope as well as change of slope of any basin and the topographic index is inversely proportional to slope. The higher value of mean error in the rugged terrain signifies the fact.

The present study concludes that for the given setting beyond $90 \mathrm{~m}$ grid spacing, the topographic index becomes unreliable with respect to the topographic index calculated from a $10 \mathrm{~m}$ grid spacing DEM. Since after $90 \mathrm{~m}$ grid spacing accuracy of 
the topographic index highly deteriorates which is more pronounced in rugged terrain.

Further investigation can be made to evaluate the accuracy of topographic index considering the following issues:

- Identification of most suitable algorithm (single flow direction or multiple flow direction) for derivation of the topographic index in a specific terrain.

- Analysis of the accuracy of topographic index on the hydrological model outcome and their relationship.

- Applicability of the present study in various climatic regions considering more number of watersheds.

\section{Acknowledgements}

Authors are thankful to Indian Institute of Remote Sensing, Dehradun and International Institute of Geo-information Science and Earth Observation (ITC), The Netherlands, for providing the data and support for this research. Authors are also thankful to the anonymous reviewers for their comments.

\section{References}

Baltsavias E, Kocaman S and Wolff K 2007 Geometric and radiometric investigations of Cartosat-1 data; In: ISPRS Hannover Workshop 2007, High Resolution Earth Imaging for Geospatial Information, Hannover, Germany, May 29-June 1.

Beven K and Kirkby M J 1979 A physically based variable contributing area model of basin hydrology; Hydrol. Sci. Bull. 24 43-69.

Brasington J and Richards K 1998 Interactions between model predictions, parameters and DTM scales for topmodel; Comput. Geosci. 24(4) 299-314.

Burrough P A, Wilson J P and Gaans P F M V 2001 Fuzzy $\mathrm{k}$-means classification of topo-climatic data as an aid to forest mapping in the Greater Yellowstone Area, USA; Landscape Ecol. 16 523-546.

Cai X and Wang D 2006 Spatial autocorrelation of topographic index in catchments; J. Hydrol. 328 581-591.

Chappell N A, Vongtanaboon S, Jiang Y and Tangtham N 2006 Return-flow prediction and buffer designation in two rainforest headwaters; Forest Ecol. Manag. 224 131-146.

Dale M R T and Fortin M J 2002 Spacial autocorrelation and statistical tests in ecology; Ecoscience 9(2) 162-167.

Demoulin A, Bovy B, Rixhon G and Cornet Y 2007 An automated method to extract fluvial terraces from digital elevation models: The Vesdre valley, a case study in eastern Belgium; Geomorphology 91 51-64.

Dragut L and Eisank C 2011 Object representations at multiple scales from digital elevation models; Geomorphology 129 183-189.

Gómez-Plaza A, Martínez-Mena M, Albaladejo J and Castillo V M 2001 Factors regulating spatial distribution of soil water content in small semiarid catchments; J. Hydrol. 253 211-226.

Goodchild M F 1986 Spatial Autocorrelation: Concepts and Techniques in Modern Geography; Geo Books, Norwich, UK.
Grayson R B, Western A W, Chiew F H S and Blöschl G 1997 Preferred states in spatial soil moisture patterns: Local and nonlocal controls; Water Resour. Res. 33(12) 2897-2908.

Grimaldi S, Nardi F, Benedetto F, Istanbulluoglu E and Bras R L 2007 A physically-based method for removing pits in digital elevation models; Adv. Water Resour. 30 2151-2158.

Guth P L 1995 Slope and aspect calculations on gridded digital elevation models: Examples from a geomorphometric toolbox for personal computers; Zeitschrift Geomorph N.F. Suppl.-Bd. $10131-52$.

Hjerdt K N, McDonnell J J, Seibert J and Rodhe A 2004 A new topographic index to quantify downslope controls on local drainage; Water Resour. Res. 40(5) W05602.

Huang B and Jiang B 2002 AVTOP: A full integration of TOPMODEL into GIS; Environ. Modelling \& Software 17 261-268.

Irvin B J, Ventura S J and Slater B K 1997 Fuzzy and isodata classification of landform elements from digital terrain data in Pleasant Valley, Wisconsin; Geoderma 77(2-4) 137-154.

Jenson S K and Domingue J O 1988 Extraction topographic structure from digital elevation data for geographic information system analysis; Photogram. Eng. Rem. Sens. 54(11) 1593-1600.

Joshi P K, Yadav K and Sinha V S P 2011 Assessing impact of forest landscape dynamics on migratory corridors: A case study of two protected areas in Himalayan foothills; Biodiversity and Conservation 20(14) 3393-3411.

Kakembo V, Rowntree K and Palmer A R 2007 Topographic controls on the invasion of Pteronia incana (Blue bush) onto hillslopes in Ngqushwa (formerly Peddie) district, Eastern Cape, South Africa; Catena 70 185-199.

Kennelly P J 2008 Terrain maps displaying hill-shading with curvature; Geomorphology 102 567-577.

Kumar P, Verdin K L and Greenlee S K 2000 Basin level statistical properties of topographic index for North America; Adv. Water Resour. 23 571-578.

Mackey B G 1994 Predicting the potential distribution of rain-forset structural characteristics; J. Vegetation Sci. 5(1) $43-54$.

Merot P, Squividant H, Aurousseau P, Hefting M, Burt T, Maitre V, Kruk M, Butturini A, Thenail C and Viaud V 2003 Testing a climato-topographic index for predicting wetlands distribution along a European climate gradient; Ecological Modelling 163 51-71.

Moreno M, Levachkine S, Torres M, Quintero R and Guzman G 2005 Automatic geomorphometric analysis for digital elevation models; Lecture Notes in Artificial Intelligence $\mathbf{3 6 8 4} 374-381$.

Nolan B T, Healy R W, Taber P E, Perkins K, Hitt K $\mathrm{J}$ and Wolock D M 2007 Factors influencing groundwater recharge in the eastern United States; J. Hydrol. 332(1-2) 187-205.

O'Loughlin E M 1986 Prediction of surface saturation zones in natural catchments by topographic analysis; Water Resour. Res. 22(5) 794-804.

Pan F, Lidard C D P, Sale M J and King A W 2004 A comparison of geographical information systems-based algorithms for computing the TOPMODEL topographic index; Water Resour. Res. 40 1-11.

Pei T, Qin C Z, Zhu A X, Yang L, Luo M, Li B and Zhou C 2010 Mapping soil organic matter using the topographic wetness index: A comparative study based on different flow-direction algorithms and kriging methods; Ecological Indicators 10(3) 610-619.

Peifa W, Jinkang D U, Xuezhi F and Guoding K 2006 Effect of uncertainty of grid DEM on TOPMODEL: Evaluation and analysis; Chinese Geogr. Sci. 16(4) 320-326. 
Quinn P F and Beven K 1993 Spatial and temporal predictions of soil moisture dynamics, runoff, variable source areas and evapotranspiration for Plinlimon, Mid-Wales; Hydrol. Proces. 5 59-79.

Quinn P F, Beven K, Chevallier P and Planchon O 1991 The prediction of hillslope flow paths for distributed hydrological modelling using digital terrain models; Hydrol. Proces. 5 59-79.

Quinn P F, Beven K J and Lamb R 1995 The $\ln (a / \tan b)$ index: How to calculate it and how to use it within the TOPMODEL framework; Hydrol. Proces. 9 161-182.

Raaflaub L D and Collins M J 2006 The effect of error in gridded digital elevation models on the estimation of topographic parameters; Environmental Modelling 83 Software 21 710-732.

Saadat H, Bonnell R, Sharifi F, Mehuys G, Namdar M and Ale-Ebrahim S 2008 Landform classification from a digital elevation model and satellite imagery; Geomorphology $100453-464$.

Schmidt F and Persson A 2003 Comparison of DEM data capture and topographic wetness indices; Precision Agriculture 4 179-192.

Shortridge A 2007 Practical limits of Moran's autocorrelation index for raster class maps; Computers, Environment and Urban System 31 362-371.

Si B C and Farrell R E 2004 Scale-dependent relationship between wheat yield and topographic indices; Soil Sci. Soc. Am. J. 68(2) 577-587.

Tempfli K 2000 DTM accuracy assessment; In: Proceedings of 1999 ASPRS Annual Conference: From image to information: Portland, Oregon, May 17-21, Bethesda: American Society for Photogrammetry and Remote Sensing (ASPRS), 11p.

Tombul M 2007 Mapping field surface soil moisture for hydrological modeling; Water Resour. Manag. 21(11) 1865-1880.

Van Niel K P, Laffan S W and Lees B G 2004 Effect of error in the DEM on environmental variables for predictive vegetation modeling; J. Veg. Sci. 15(6) 747-756.

Vaze J, Teng J and Spencer G 2010 Impact of DEM accuracy and resolution on topographic indices; Environmental Modelling \& Software 25(10) 1086-1098.

Western A W, Grayson R B, Blöschl G, Willgoose G R and McMahon T A 1999 Observed spatial organization of soil moisture and its relation to terrain indices; Water Resour. Res. 35(3) 797-810.
Western A W, Zhou S L, Grayson R B, McMahon T A, Blöschl G and Wilson D J 2004 Spatial correlation of soil moisture in small catchments and its relationship to dominant spatial hydrological processes; J. Hydrol. 286(1-4) 113-134.

Wilson J P and Gallant J C 2000 Digital terrain analysis; In: Terrain Analysis: Principles and Applications (eds) Wilson J P and Gallant J C (New York: John Wiley \& Sons), pp. 1-27.

Wimberly M C and Reilly M J 2007 Assessment of fire severity and species diversity in the southern Appalachians using Landsat TM and ETM+ imagery; Remote Sens. Environ. 108(2) 189-197.

Wolock D M and McCabe Jr G J 1995 Comparison of single and multiple flow direction algorithms for computing topographic parameters in TOPMODEL; Water Resour. Res. 31(5) 1315-1324.

Wolock D M and Price C V 1994 Effects of digital elevation model map scale and data resolution on a topographybased watershed model; Water Resour. Res. 30(11) 3041-3052.

Wu S, Li J and Huang G H 2007 Modeling the effects of elevation data resolution on the performance of topography-based watershed runoff simulation; Environmental Modelling \& Software 22 1250-1260.

Wu S, Li J and Huang G H 2008 A study on DEM-derived primary topographic attributes for hydrological applications: Sensitivity to elevation data resolution; Appl. Geogr. 28 210-223.

Yesilnacar E and Topal T 2005 Landslide susceptibility mapping: A comparison of logistic regression and neural networks methods in a medium scale study, Hendek region (Turkey); Eng. Geol. 79(3-4) 251-266.

Yong B, Zhang W, Niu G Y, Ren L L and Qin C Z 2009 Spatial statistical properties and scale transform analyses on the topographic index derived from DEMs in China; Comput. Geosci. 35(3) 592-602.

Yue T X, Du Z P, Song D J and Gong Y 2007 A new method of surface modelling and its application to DEM construction; Geomorphology 91 161-172.

Zhang W and Montgomery D R 1994 Digital elevation model grid size, landscape representation, and hydrologic simulation; Water Resour. Res. 30(4) 1019-1028.

Zinko U, Seibert J, Dynesius M and Nilsson C 2005 Plant species numbers predicted by a topography-based groundwater flow index; Ecosystem 8(4) 430-441. 